\title{
A Numerical Study for Upgrading the Container Terminal of Port-Said West Port
}

\author{
Elsayed M. Galal
}

\begin{abstract}
Over the past few decades, the rapid expansion of trade has led to a tremendous increase in cargo handling between the various continents. This continuous growth has motivated shipping lines to increase the ships sizes which may lead to the need to develop many of container terminals. Generally, the complete demolition of an existing quay wall construction and replacing by a new structure is often not possible due to the high costs. The deepening and upgrading of the existing quay walls is the next option. This means that the existing quay walls will have to retain more soil than they actually designed for. The general approach for this case is to review the original design and subsequent improvement calculations. The present study was carried out to evaluate numerically, using the numerical model PLAXIS 2D, the possibility to upgrade the existing open-piled quay wall structure of the container terminal of Port Said West port, Egypt. A rehabilitation technique consisting of new fender piles and new box sheet pile panels had been selected to accommodate the berth deepening and the heavier new container crane loads. The evaluation had been carried out through the review of the original design and subsequent improvement analyses under the development two cases defined as Pre- and Post-upgrading cases. The results showed that the structure after upgrading was able to keep the stability of the soil to its previous levels before upgrading and quay wall structure elements were able to resist the deepening effect plus the increase in crane loads.
\end{abstract}

Key words: Deepening; Quay Walls; Open-piled; Numerical Modeling; PLAXIS.

\section{INTRODUCTION}

Nowadays, one of the most common challenges for ports is its need to increase the depth in front of the toe of the existing quay wall structures. A set of complex technical problems arises when the deepening has to be performed near quay wall structures. In addition to the deepening challenges, it usually entail higher operation loads (mooring, berthing, cranes) and sometimes also storage loads on the structures due to the need to berth larger ships. Therefore, constructive adjustments have to be made to the quay walls, to provide sufficient strength and stability (PIANC, 2015 [17]). Recently, Finite Element Method, FEM, has become more popular as a soil response prediction tool. This has led to increase pressure on researchers to develop more comprehensive descriptions for soil behavior, which in turn leads to more complex constitutive relationships. Some authors in the literature take into account the ability of using the numerical work to examine the behavior of quay wall structures to solve the technical problems arises due to deepening and upgrading.

The effect of deepening in front of quay wall structure has been investigated by a number of researchers. Elskensl and Bols, 1998 [8] concluded that combining the techniques of the Very High Pressure (VHP) grouting, installation of ground anchors and drains had

\footnotetext{
${ }^{I}$ Assistant Professor, Faculty of Engineering, Port Said University, Egypt,Email: elsayed.galal@eng.psu.edu.eg
}

already proven to be an economical and technical solution for deepening quay walls. A research on application of the analytical method to study the effect of dredging on piles and diaphragm wall-supported berthing structures had been carried by Muthukkumaran and Sundaravadivelu, 2007[13]. Both El-Naggar, 2010 [7] and Mollahasani, 2014 [12] investigated numerically the rehabilitation of steel sheet piling quay walls using additional grouting tie-rods. The results showed that the anchored wall and surrounding soil showed more stabilized behavior when the grouted anchors are used. Premalatha et al., 2011[18] carried out a numerical study on pile group supporting the berthing structures subjected to berthing/mooring forces and the forces resulted from deepening operations. Subha, 2012 [20] analyzed the lateral response of pile and diaphragm wall during dredging and seismic loading on the dredged soil numerically. Habets et al., 2016 [11] investigated the suitability of the performance-based design method to evaluate permanent deformations and amounts of (repairable) damage under seismic loading for anchored sheet pile quay walls that were not purposely designed for seismic loads. Recently, Tolba et al., 2017 [21] demonstrated a verification study for the ability of developing the diaphragm quay wall existing at the container terminal of Port Said East Port.

Generally, due to the high costs and the environmental boundaries, the complete demolition of an existing quay wall and replacing by a new structure is not preferred to be the first option. Therefore, the deepening and upgrading of the existing quay walls is the next option. 
A number of case histories about the deepening and upgrading of existing quay walls have been reported in the literature. Paparis et al., 2004 [15] studied the effect of berth deepening and strengthening to accommodate larger vessels for Port Elizabeth Container Terminal. Cornell et al., 2007 [3] suggested a system consisting of soldier piles and sheet pile panels to allow berth deepening in front of the berth structure. Deblauwe et al., 2013 [5] reported that in order to deepen and renovate the existing container Zeebrugge quay wall, a new front combi-wall consisting of a concrete relieving floor on driven concrete piles and a steel sheet pile retaining wall was erected. De Gijt and Broeken, 2013 [4] introduced a number of upgrade, repair, or deepening of quay walls examples all over the world. Douairi, 2013 [6] studied many options for creating extra depths in front of quay walls of which not all have been used in practice. Oung and Brassinga, 2015 [14] discussed widely the risks of upgrading existing quay walls such as deepening in front of quay walls and increasing the loads on the quay surface. Among the various concepts evaluated to upgrade the existing X-Ray wharf located on the southeastern corner of inner Apra Harbor located in U.S. Naval Base Guam, Varatharaj et al., 2016 [22] proposed that an effective constructing a new wharf in front of the existing wharf was found to be the most effective solution to meet the current seismic standards and deepening operation. A new sheet pile bulkhead wall approximately $10.7 \mathrm{~m}$ away from the existing sheet pile bulkhead will be constructed and the space between the new and old sheet pile bulkheads will be filled with improved granular backfill.

The main purpose of this work is to evaluate numerically the possibility of deepening and upgrading the existing open-piled quay wall structure of the container terminal of Port Said West Port and to provide recommended rehabilitation techniques for resisting impacts resulted from deepening effect plus the increase of crane loads.

\section{EXISTING BERTHING STRUCTURE}

\subsection{Structural Elements}

The case study quay wall structure is located in PortSaid West Port, Egypt. Port Said has a strategic location at the crossroads of the northern entrance to the Suez Canal and the Mediterranean Sea as shown in Figure 1. The existing quay wall, as designed, is capable of accommodating a third-generation container ship with drafts up to $12 \mathrm{~m}$. To satisfy the berthing facility of the vessel, the ground level was dredged up to an elevation of $-14.0 \mathrm{~m}$. The quay wall structure has a length of 350 $\mathrm{m}$ and width of $33.5 \mathrm{~m}$. The structure consists of a horizontal deck supported on 7 rows of steel pipes of 7 $\mathrm{mm}$ thickness and 700-mm diameter filled with concrete, while underneath the deck with a slope (1: 2.8) revetment is lying in order to withstand the wave attack and the currents caused by the propellers and the bow thrusters of the ships. The piles are terminated at a depth of $-45.0 \mathrm{~m}$ level. The quay wall structure resists the lateral loads by connecting the deck to an existed rear sheet pile wall. There are two anchored sheet piles at levels $-20.00 \mathrm{~m}$ and $-6.00 \mathrm{~m}$ with spacing $50.0 \mathrm{~m}$. Tie rods with $2.70 \mathrm{~m}$ spacing attached to the system to provide the lateral stability of the structure. Figure 2 shows the geometry of the case study quay wall structure.

\subsection{Geotechnical Data and Existing loads}

The geotechnical investigation carried out at several locations in the site which reveals that there are considerable variations in the soil profile. The geotechnical data used in the analysis are shown in the typical borehole as in Figure 3.

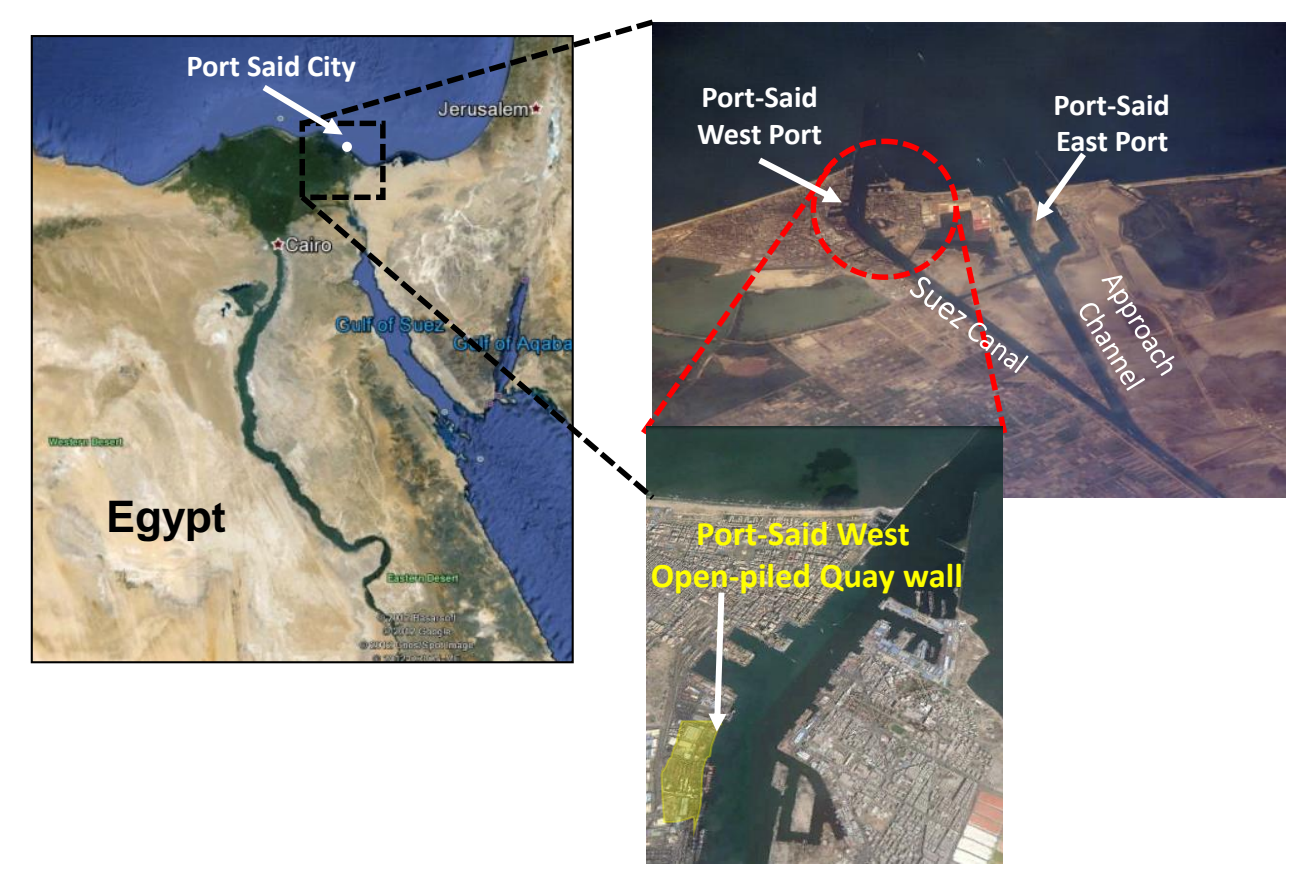

Figure 1: Location of the studied quay wall. 


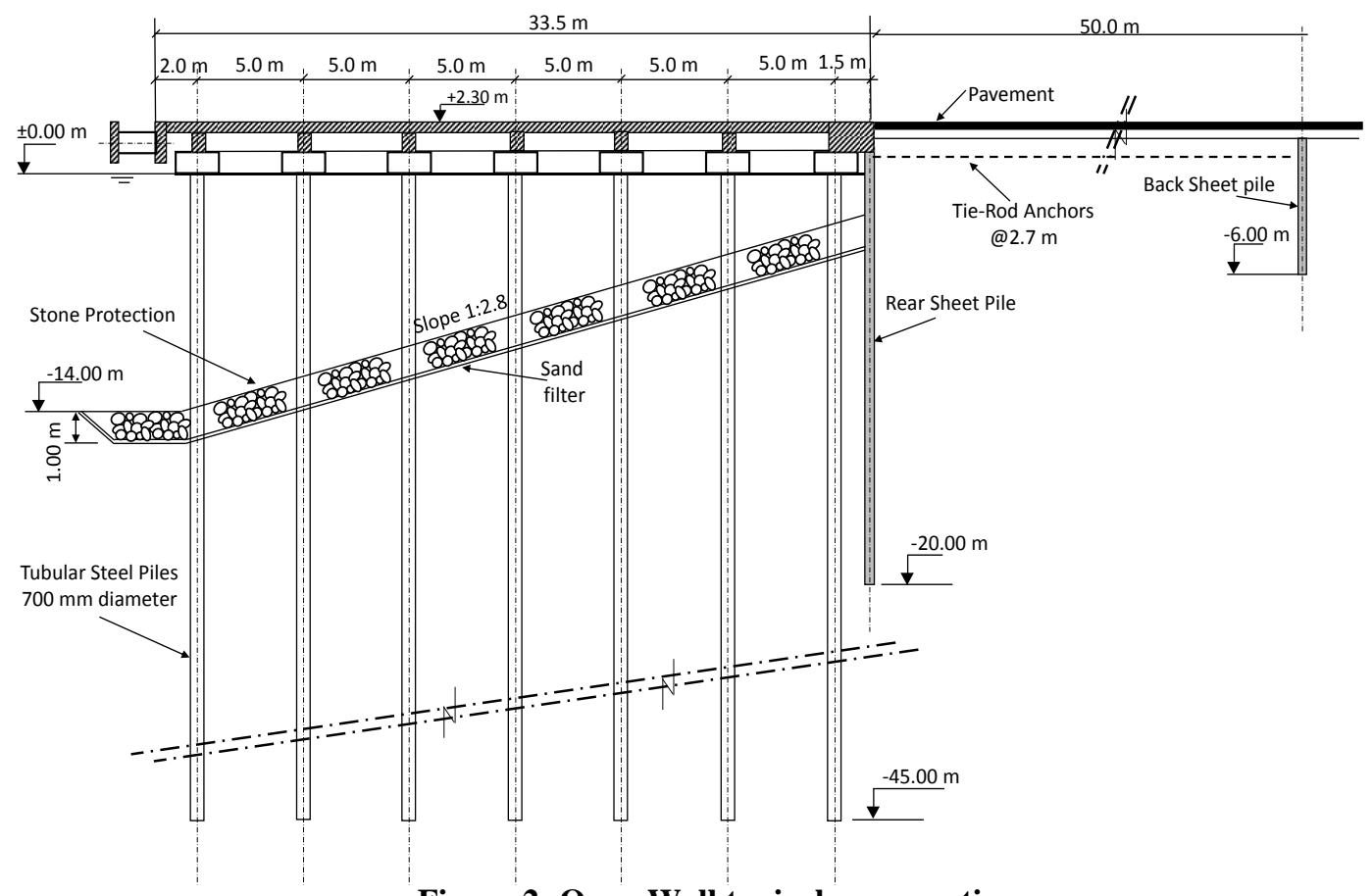

Figure 2: Quay Wall typical cross-section.

At the stage of the first design of the study case quay wall, many types of loads had been taken into consideration. In addition to the structure self-load, there are two types of loads, modeled in static analysis, could be applied in this study, i.e. distributed loads and point loads as shown in Table 1.

\section{DESCRIPTION OF APPROACH}

The general approach of this research study was to evaluate numerically, using the numerical model PLAXIS 2D, the possibility to upgrade the open-piled quay wall structure of the container terminal of Port Said West Port.

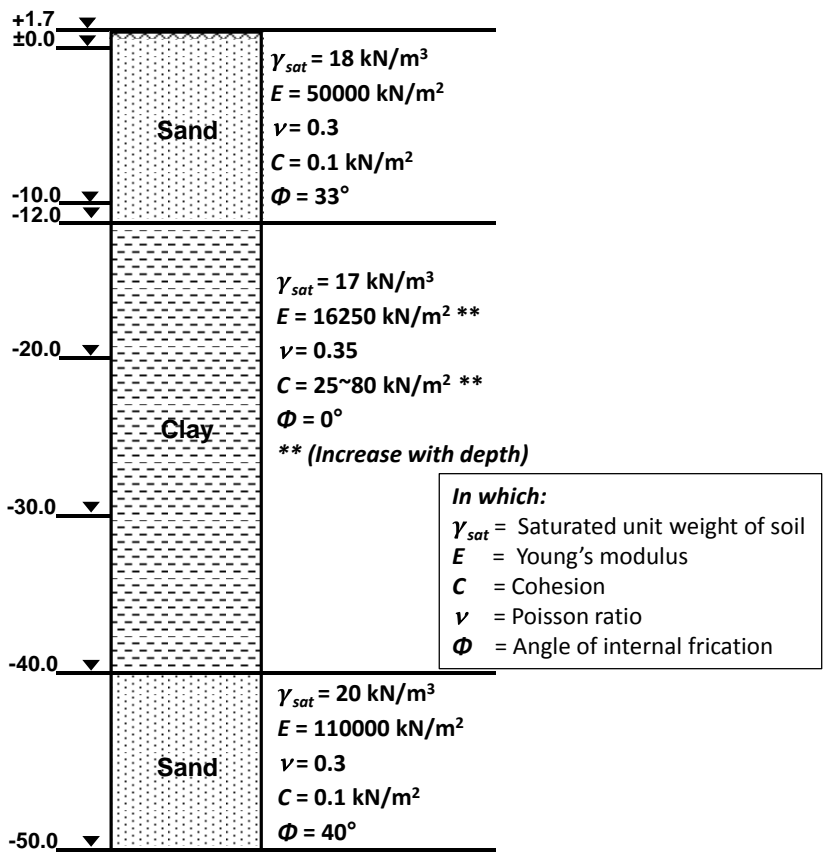

Figure 3: Typical borehole details.
Table 1: Loads considered for the first design of the quay wall.

\begin{tabular}{|c|c|}
\hline $\begin{array}{c}\text { Type of } \\
\text { load }\end{array}$ & Value \\
\hline $\begin{array}{c}\text { Berthing } \\
\text { loads }\end{array}$ & $25 \mathrm{KN} / \mathrm{m}^{\prime}$ \\
\hline \hline $\begin{array}{c}\text { Mooring } \\
\text { loads }\end{array}$ & $135 \mathrm{KN} / \mathrm{m}^{\prime}$ \\
\hline \hline $\begin{array}{c}\text { Crane } \\
\text { loads }\end{array}$ & Vertical crane load $=250 \mathrm{KN} / \mathrm{m}^{\prime}$ \\
\hline $\begin{array}{c}\text { Surcharge } \\
\text { loads }\end{array}$ & $\begin{array}{c}\text { Platform surface load }=20 \mathrm{KN} / \mathrm{m}^{2} \\
\text { Cargo yard surface load }=40 \mathrm{KN} / \mathrm{m}^{2}\end{array}$ \\
\hline
\end{tabular}

The evaluation has be carried out through the review of the original design and subsequent improvement analyses under the development two cases/scenarios. The first case/scenario was representing here the existed quay wall before development (Pre-upgrading Case) as a baseline in which the dredged level in front of the quay wall is $-14.0 \mathrm{~m}$. While, the other case was representing the quay wall renovation raised due to deepening to the level $-16.0 \mathrm{~m}$ plus the increase of the crane loads (Postupgrading Case).

Therefore, the two cases were modeled and in each case the following results are checked; displacements, deflections, and straining actions (normal forces, and bending moments) for structure elements. In addition, the overall stability for the quay wall in both cases are checked. Furthermore, after conducting this evaluation, the improvement recommendations have been carried out. Table 2 shows the dredged levels and crane loads used to analyze the berthing structure performance under both cases. 
Table 2: Dredged levels and crane loads used in development cases.

\begin{tabular}{|c|c|c|}
\hline $\begin{array}{c}\text { Development } \\
\text { Cases }\end{array}$ & $\begin{array}{c}\text { Dredged } \\
\text { level }(\mathbf{m})\end{array}$ & $\begin{array}{c}\text { Crane } \\
\text { load } \\
\left(\mathrm{KN} / \mathbf{m}^{\prime}\right)\end{array}$ \\
\hline $\begin{array}{c}\text { Pre-upgrading } \\
\text { Case }\end{array}$ & -14.00 & 250 \\
\hline \hline $\begin{array}{c}\text { Post- } \\
\text { upgrading } \\
\text { Case }\end{array}$ & -16.00 & 300 \\
\hline
\end{tabular}

In order to resist the additional straining actions resulted from deepening and crane loads, represented by the Post-upgrading case, a system inserted in front of the existing quay wall structure keeping the old contact surface between the wall and the ships with no change.
The selected rehabilitation technique consisting of new fender piles driven to a depth of $-40.0 \mathrm{~m}$ and new box sheet pile panels in between driven to a depth of $20.0 \mathrm{~m}$. The new fender piles keep the contact surface between the ship and the existing wall structure at the same level. These piles carry a new fender system in between the old fenders. The new fenders are highenergy absorbent "unit" type fenders. The units are typically spaced along the quay wall with the assumption that each could handle the entire increasing in the berthing energy. So that, the design philosophy adopted at this stage was that the structure after upgrading would be returned to its current stability levels. Figure 4 shows a layout of the modified quay wall after upgrading.

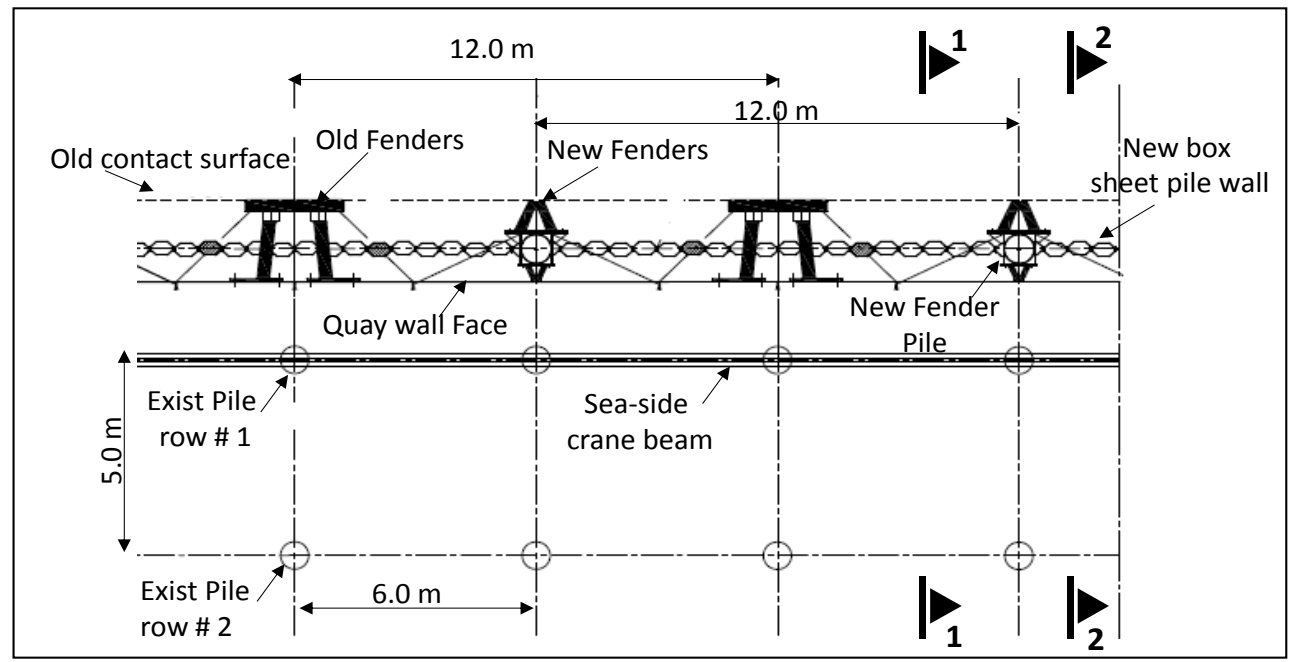

(a) Plan

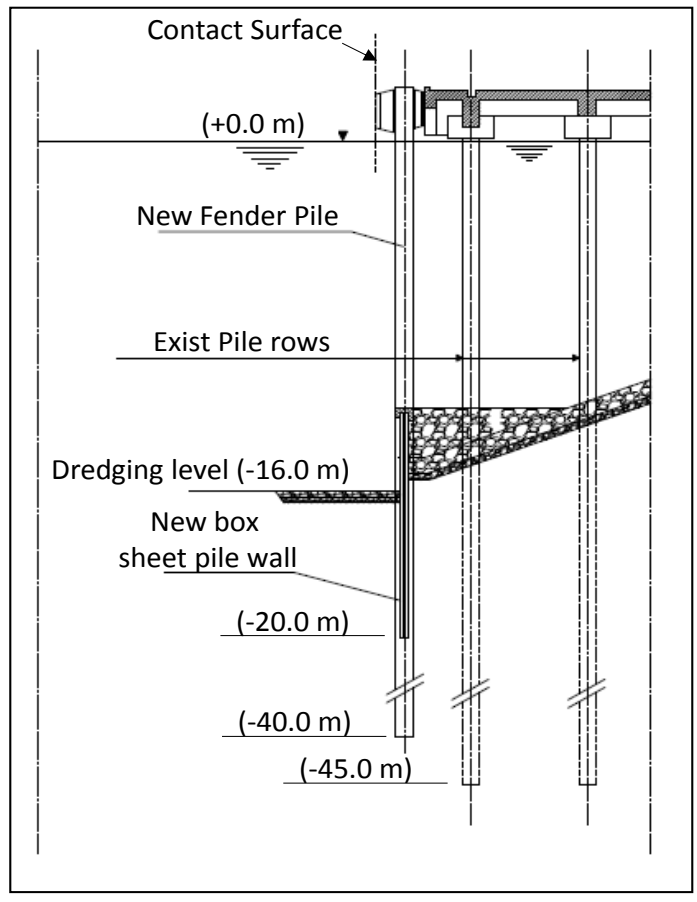

(b) Sec. 1-1

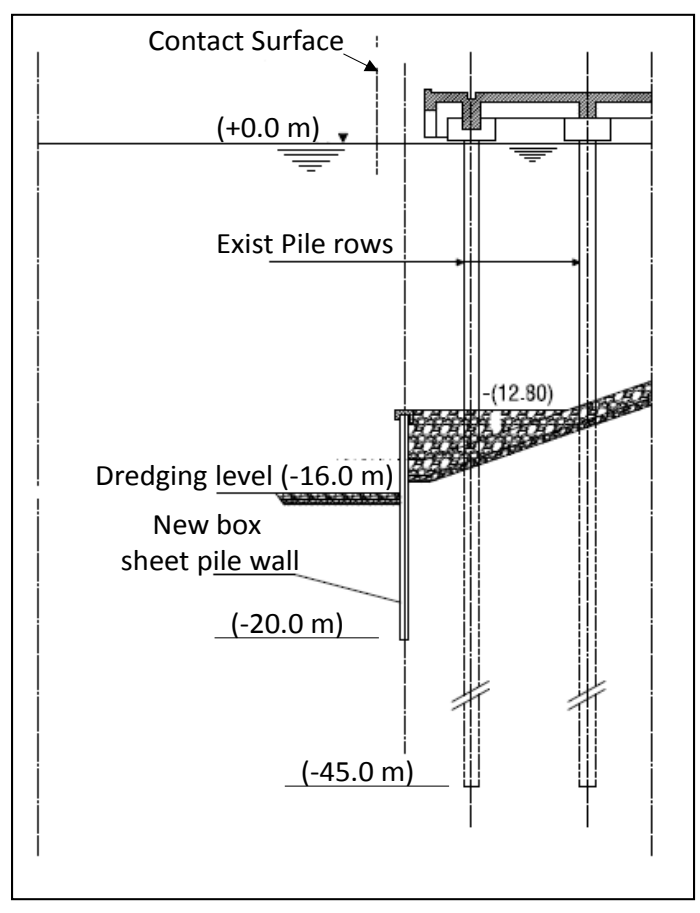

(c) Sec. 2-2

Figure 4: Layout of the modified quay wall after upgrading 


\section{NUMERICAL MODELING}

PLAXIS 2D software, a 2D finite-element soilstructure-interaction program, have wide applications in solving numerical geotechnical problems, especially in the field of marine structures. Generally, PLAXIS was used to model the various berths and loading conditions to allow analysis of complex soil stratigraphy and berth construction under static and seismic loading conditions. In this study, PLAXIS 2D Version 8.2 has been used for static condition only (Brinkqreve et al., 2004 [2]). In this study, the same dimensions of the field berthing structure are adopted. The boundary of stratigraphy of the model is taken as two times greater than the structural area, so that no effect of the boundaries. PLAXIS 2D has been used to model the existing berthing structure using the concept of plain strain condition, with the piles represented as equivalent sheetpile wall. The equivalent sheet-pile walls are modeled with beam-column elements connected to the finite element mesh, and the soil strata are represented by 15 nodded triangular elements of elastic-plastic MohrCoulomb model. Soil-structure interaction is modeled by means of a bilinear Mohr-Coulomb model.

The pile in the 2D model must be converted to an equivalent sheet-pile wall where the piles are replaced by an equivalent sheet-pile wall with flexibility equal to the average of the piles and soil. Randolph, 1981[19] showed the equivalent sheet pile wall representation of piles for plane strain 2D finite element analysis. For example, the data entry for the walls "plates", the 2D model requires the axial stiffness $E A$, flexural rigidity $E I$ and Poisson's ratio $v$. Therefore, from the ratio EI/EA, an equivalent thickness for an equivalent plate $D_{e q}$ is automatically calculated as $D_{e q}=(12 * E I / E A)^{1 / 2}$. The difference between 2D and 3D for representing piles has been studied by Galal et al., 2016 [10].

\section{RESULTS AND DISCUSSION}

In this section, the $2 \mathrm{D}$ analysis of the quay wall is carried out under the total combination case of static loads which include the dead load, surcharge load, vertical and horizontal crane loads, and mooring loads. The results of the 2D model of the quay wall were analyzed for the previous two cases that mentioned in Table 2. The resulting displacements and straining actions are used for checking the structural elements, the structure serviceability, and the overall stability of the quay wall. The results obtained are represented in the form of stresses, bending moment, shear, displacements, etc. for each element of the quay wall structure. In this section, the results will be classified according to the behavior of each case with respect to the structure and the soil domains.

\subsection{Soil Domain}

Figure 5 (a) shows the typical 2D deformed finite element mesh of the quay wall structure and soil domain for the Pre-upgrading case. The displacements

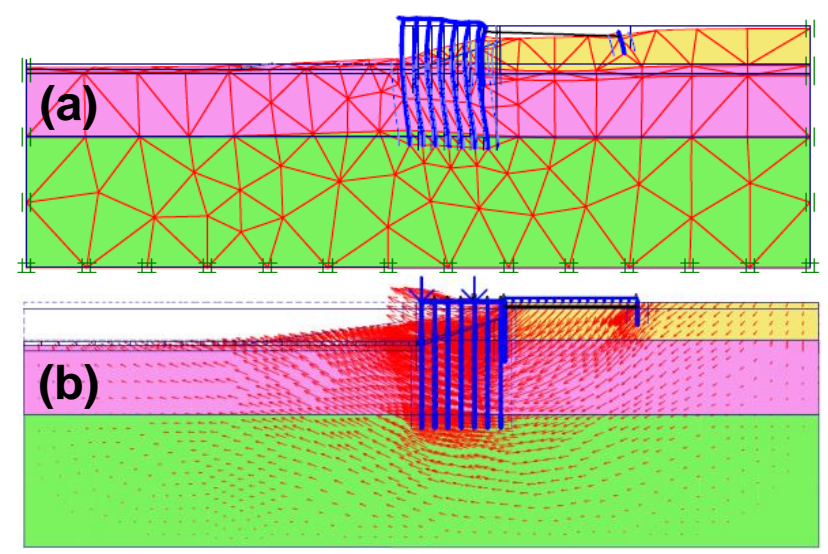

Figure 5: Typical 2D finite element meshes of the studied quay wall for the Pre-upgrading case: (a) Deformed mesh, and (b) Displacement Vectors.

shown in the figures are scaled up to 100 times. Minor vertical displacements along the deck show that it will tilt towards the sea, but will not cause instability to the quay wall. Small horizontal displacements are also observed; however, piles are sufficiently flexible to accommodate it and are considered to be acceptable. Also, from the deformed shape of the mesh, it can be observed that the failure zone such as the critical slip circle may pass through the top layers. While, Figure 5 (b) shows the displacement vectors for the same case. It is clear that the displacement mechanism of the structure is a rotational mode. The figure also shows that the soil behind the quay wall moves downward, the soil below the quay wall moves horizontally and the soil in front of the quay moves upward. These results are repeated for the other case, post-upgrading case, with the same trend but with a higher values due to deepening effect plus the increase of the crane loads.

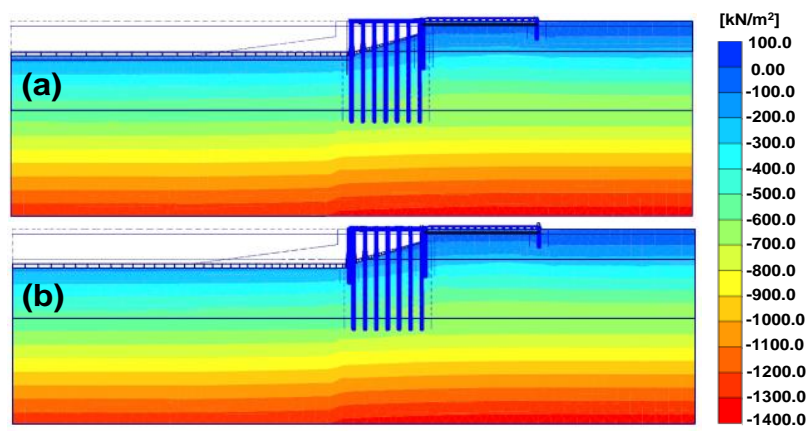

Figure 6: Overall total stresses for: (a) Preupgrading case, and (b) Post-upgrading case.

Figure $6(\mathrm{a}$, and $\mathrm{b})$ shows the overall shape of total stresses resulted from both 2D analysis for the pre- and post- upgrading cases. The results show that the extreme total stresses, which located far away from the quay wall, is almost same for both cases and equal to -1380 $\mathrm{kN} / \mathrm{m}^{2}$. The values of the total stresses in the case of 
post-upgrading show some unremarkable increase than of the case of pre-upgrading close to the quay wall due to the removal of soil by deepening.

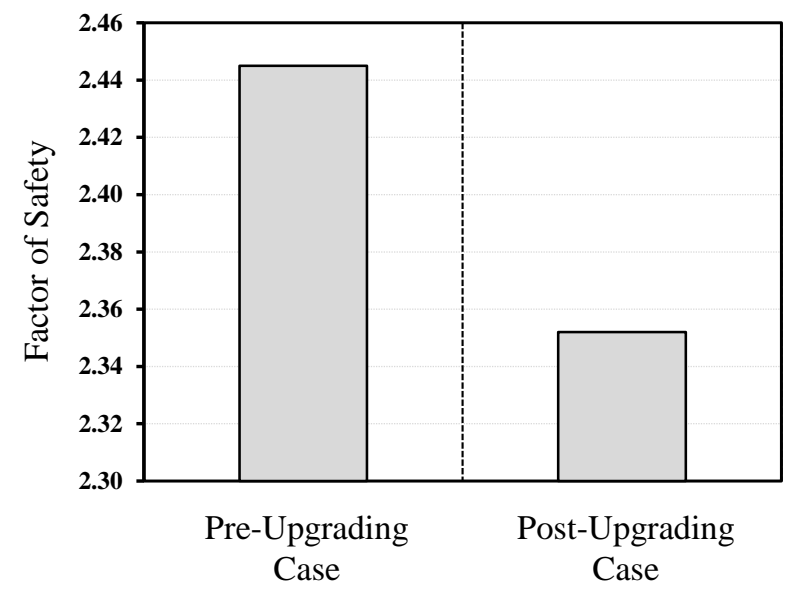

Figure 7: $\varphi-$ c reduction factor of safety.

For determining the factor of safety for the soil, the shear strength reduction method was used. The shear strength reduction method is better than the other methods investigating slopes stability (Farshidfar, and Nayeri, 2015 [9]). One of the advantages of this method is that there is no need to the primary guess at determination of critical failure surface. Recently, this method is used increasingly than before due to the highspeed computer systems. Generally, the soil shear strength is gradually decreased by PLAXIS software as long as the first indications of failure appear. Safety factor is defined here as the ratio of real shear strength of soil to the reduced shear strength. Figure 7 shows the factor of safety for the pre- and post-upgrading cases. It is obvious that the factor of safety of the soil decreased due to deepening plus the increase of crane loads by about $4 \%$.
At the end of this section, the pervious results indicated that, in spite of the deepening effect and the increase of the crane loads, the structure after upgrading was able to keep the stability of the soil to its previous levels before upgrading.

\subsection{Structure Domain}

In this section, the results of straining actions and the deformations of structural elements such as piles, sheet piles, and deck beams for the two cases will be discussed.

\subsubsection{Piles}

As mentioned before, the present studied quay wall consists of 7 rows of piles; $1^{\text {st }}$ pile, and $5^{\text {th }}$ pile were selected to present its results due to its importance as they are supporting the crane beams. Figure 8 and Figure 9 show the comparison between the pre- and postupgrading cases for the resulted variations of horizontal displacement, normal force, and bending moment for $1 \mathrm{st}$ pile and 5th pile, respectively.

With respect to the variations of the resulted displacements values shown in Figure 8 (a) and Figure 9 (a), the results show that, in spite of using the suggested system, there is an average increase in horizontal displacement with about $7 \%$. Furthermore, with respect to variation of the bending moment values, the results show that there an average increase in bending moment with about $22 \%$ as shown in Figure 8 (b) and Figure 9 (b). Finally, due to increase in the crane loads, the results of normal force variations show that there is also an average increase by about $25 \%$ as shown in Figure 8 (c) and Figure 9 (c). In the following section, the pile sections will be checked and compared to the pile's design criteria for both strength and serviceability in order to satisfy the requirements of (ACI 318-95, 1995 [1]).

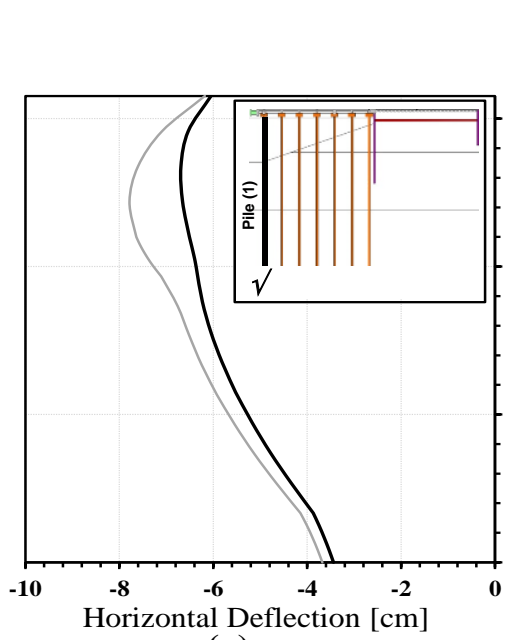

(a)

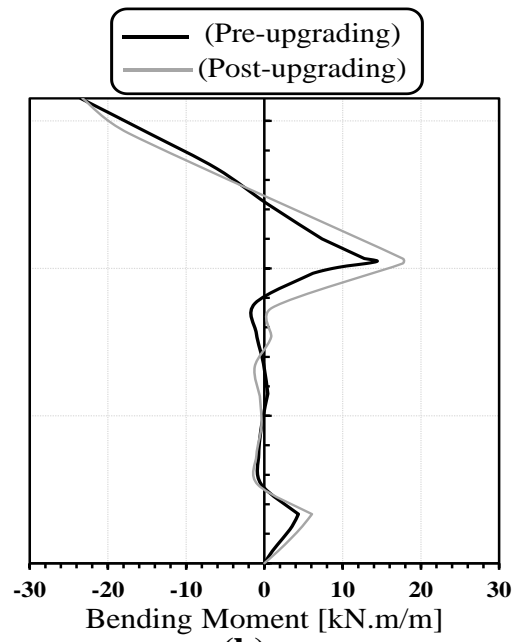

(b)

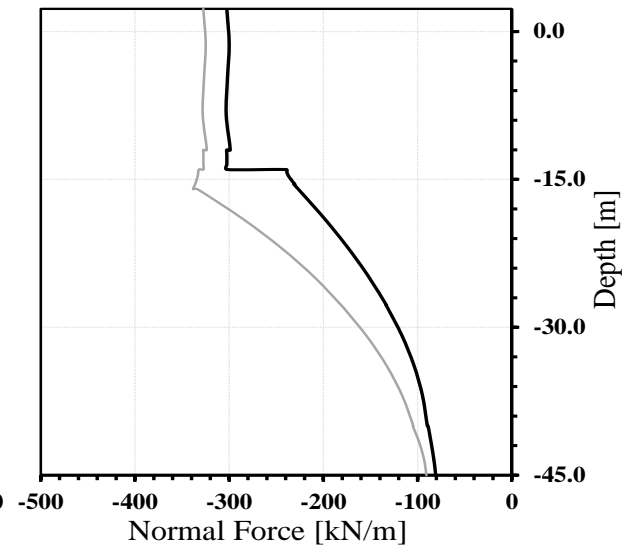

(c)

Figure 8: Comparison between pre- and post-upgrading cases for $1^{\text {st }}$ pile for: (a) Horizontal displacement, (b) Bending moment, and (c) Normal force. 


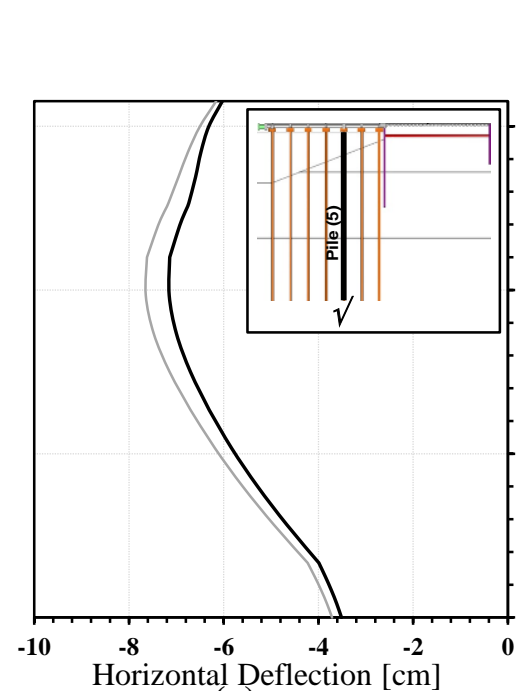

(a)

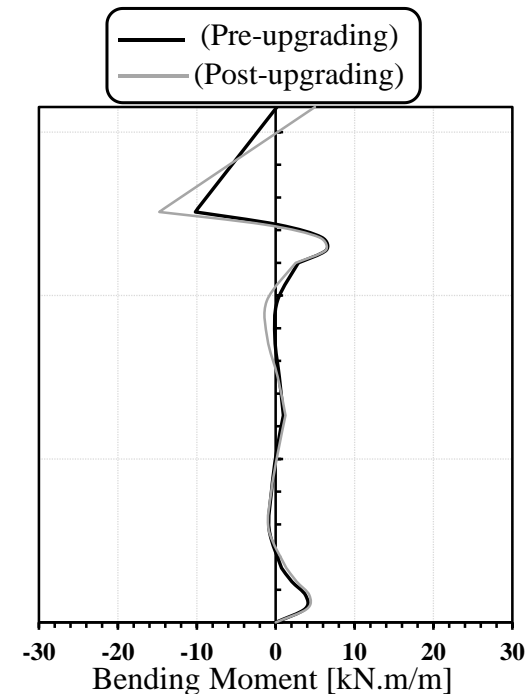

(b)

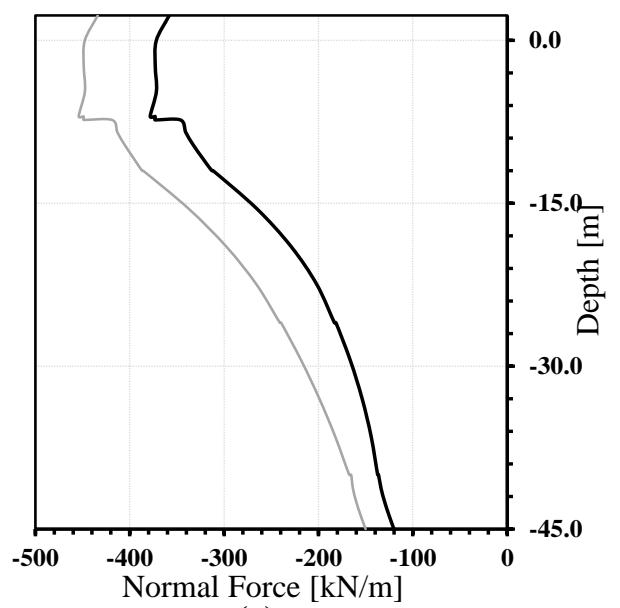

(c)

Figure 9: Comparison between pre- and post-upgrading cases for $5^{\text {th }}$ pile for: (a) Horizontal displacement, (b) Bending moment, and (c) Normal force.

The interaction diagrams were made to check if the cross section of existing piles could able to resist the additional straining actions. For this purpose, a two design points had been selected for each pile in each case. The first point has coordinates of maximum bending moment and its corresponding normal force. While the other design point has coordinates of maximum normal force and its corresponding bending moment. Figure 10 (a, and b) shows the interaction diagrams for the $1^{\text {st }}$ pile and $5^{\text {th }}$ pile. The results show that all the design points are lying inside the chart which means that the section is safe for all design cases.

Regardless the capability of the structural elements to resist the additional straining action induced by the deepening and the crane loads, other important factors must be taken into consideration. The tilting angle of the piles due to deflection is considered one of these important factors. Even though the computed results of horizontal deflection of the piles may considered acceptable, the tilting of all piles has been checked and compared with the allowable values.

Table 3 shows the results of the tilting angles for each pile in both cases. Therefore, it is clear that all the piles didn't exceed the allowable values.

\subsubsection{Sheet Piles}

For the studied quay wall structure, the lateral loads are resisted by connecting the deck to a rear sheet pile wall which anchored by tie rod to the back sheet pile as shown in Figure 2. So, it is important to check the effect of the deepening and the increase in crane loads.
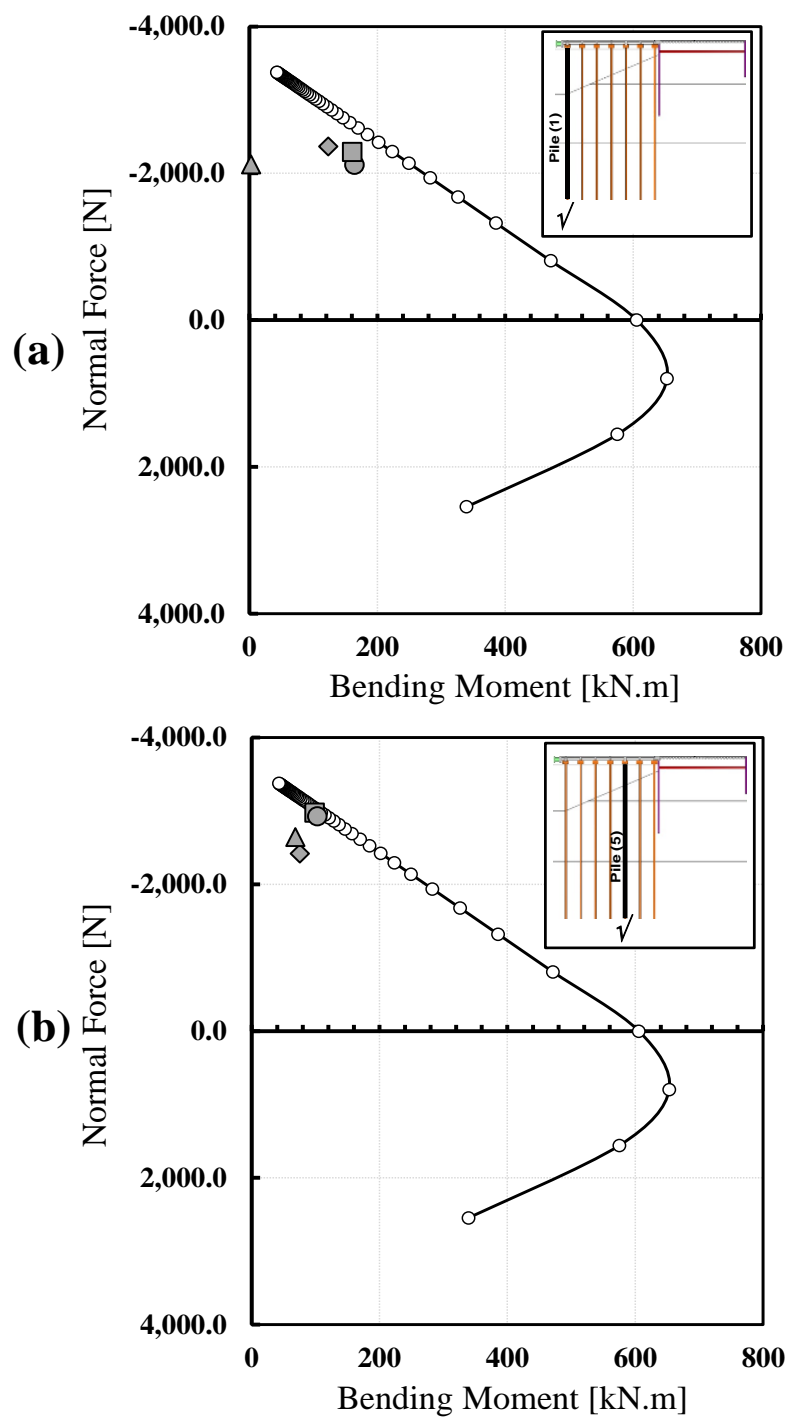

Figure 10: Interaction diagrams for: (a) $1^{\text {st }}$ Pile, and (b) $5^{\text {th }}$ Pile. 
Table 3: Piles tilting angles.

\begin{tabular}{|c|c|c|c|c|c|c|c|c|}
\hline \multirow{2}{*}{ Cases } & \multicolumn{7}{|c|}{$\theta$ Actual in $\left(^{\circ}\right)$} & \multirow{0}{*}{$\begin{array}{c}\text { Allowable } \\
\text { in ( }\end{array}$} \\
\cline { 2 - 8 } & Pile 1 & Pile 2 & Pile 3 & Pile 4 & Pile 5 & Pile 6 & Pile 7 & \\
\hline $\begin{array}{c}\text { Pre- } \\
\text { upgrading } \\
\text { Case }\end{array}$ & $\approx 0.1^{\circ}$ & $\approx 0.1^{\circ}$ & $\approx 0.1^{\circ}$ & $\approx 0.1^{\circ}$ & $\approx 0.1^{\circ}$ & $\approx 0.1^{\circ}$ & $\approx 0.1^{\circ}$ & $2^{\circ}-3^{\circ}$ \\
\hline $\begin{array}{c}\text { Post- } \\
\text { upgrading } \\
\text { Case }\end{array}$ & $\approx 0.1^{\circ}$ & $\approx 0.1^{\circ}$ & $\approx 0.1^{\circ}$ & $\approx 0.1^{\circ}$ & $\approx 0.1^{\circ}$ & $\approx 0.1^{\circ}$ & $\approx 0.1^{\circ}$ & $2^{\circ}-3^{\circ}$ \\
\hline \hline
\end{tabular}

Figure 11 and Figure 12 show the comparison between the pre- and post- upgrading cases for the resulted variations of horizontal displacement, normal force, and bending moment for rear and back sheet piles, respectively. By observing the horizontal displacement shown in Figure 11 (a) and Figure 12 (a), the results show that there a small remarkable increase by about $5 \%$. While, the results of bending moment show that the increasing ratio is about $8 \%$ as shown in Figure 11 (b) and Figure 12 (b). Finally, the results of normal force show that there is no change occurred as shown in Figure 11 (c) and Figure 12 (c). Therefore, at the end of this section, the existing sheet piling system able to resist the extra straining actions resulted due to the deepening effect plus the increase in crane loads.

\subsubsection{Deck}

One of the main advantages of 3D modeling, which is absent in 2D modeling, is its ability to calculate the internal forces for the deck slab and beams. Therefore, the differential settlement between sea-side and land-side crane beams for the two cases has been calculated as shown in Table 4. The differential settlement between beams is important factor to determine whether the quay
Table 4: Differential settlement between sea-side and land-side crane beams for the two cases.

\begin{tabular}{|c|c|c|c|c|}
\hline Case & $\begin{array}{c}\text { Sea-Side beam } \\
\text { Av. Settlement } \\
(\mathbf{c m})\end{array}$ & $\begin{array}{c}\text { Sea-Side beam } \\
\text { Av. settlement } \\
(\mathbf{c m})\end{array}$ & $\begin{array}{c}\text { Differential } \\
\text { settlement } \\
(\mathbf{c m})\end{array}$ & $\begin{array}{c}\text { Allowable } \\
\text { Differential } \\
\text { settlement }(\mathbf{c m})\end{array}$ \\
\hline $\begin{array}{c}\text { Pre- } \\
\text { upgrading } \\
\text { Case }\end{array}$ & 2.742 & 0.862 & 1.88 & $\begin{array}{c}\text { crane rail } / 1000= \\
2 \mathrm{~cm}\end{array}$ \\
\hline $\begin{array}{c}\text { Post- } \\
\text { upgrading } \\
\text { Case }\end{array}$ & 2.791 & 0.801 & 1.99 & $\begin{array}{c}\text { crane rail } / 1000= \\
2 \mathrm{~cm}\end{array}$ \\
\hline
\end{tabular}

quay wall operation will efficiently continue or not according to the allowable limits (PIANC, 2001 [16]). The results show that it is clear that the differential settlement between sea side and land side crane beams is acceptable for the quay wall and crane operation. Therefore, for more safety and in order to prevent further erosion and to restore the stability, a grout body, using Deep Mixing Method, should be added in front of the selected upgrading technique. The Deep Mixing Method (DMM) is described as a ground modification technique that improves the quality of soil by in situ auger mixing of soils extending to large depths with binders such as cement, lime, or other types. DMM is currently accepted worldwide as a ground improvement technology to improve strength, deformation and permeability properties of soil.

Therefore, with respect to the structure domain, it could be concluded that the selected rehabilitation technique could help the existing quay wall structure elements to resist the additional straining actions resulted from the deepening effect plus the increase in crane loads.
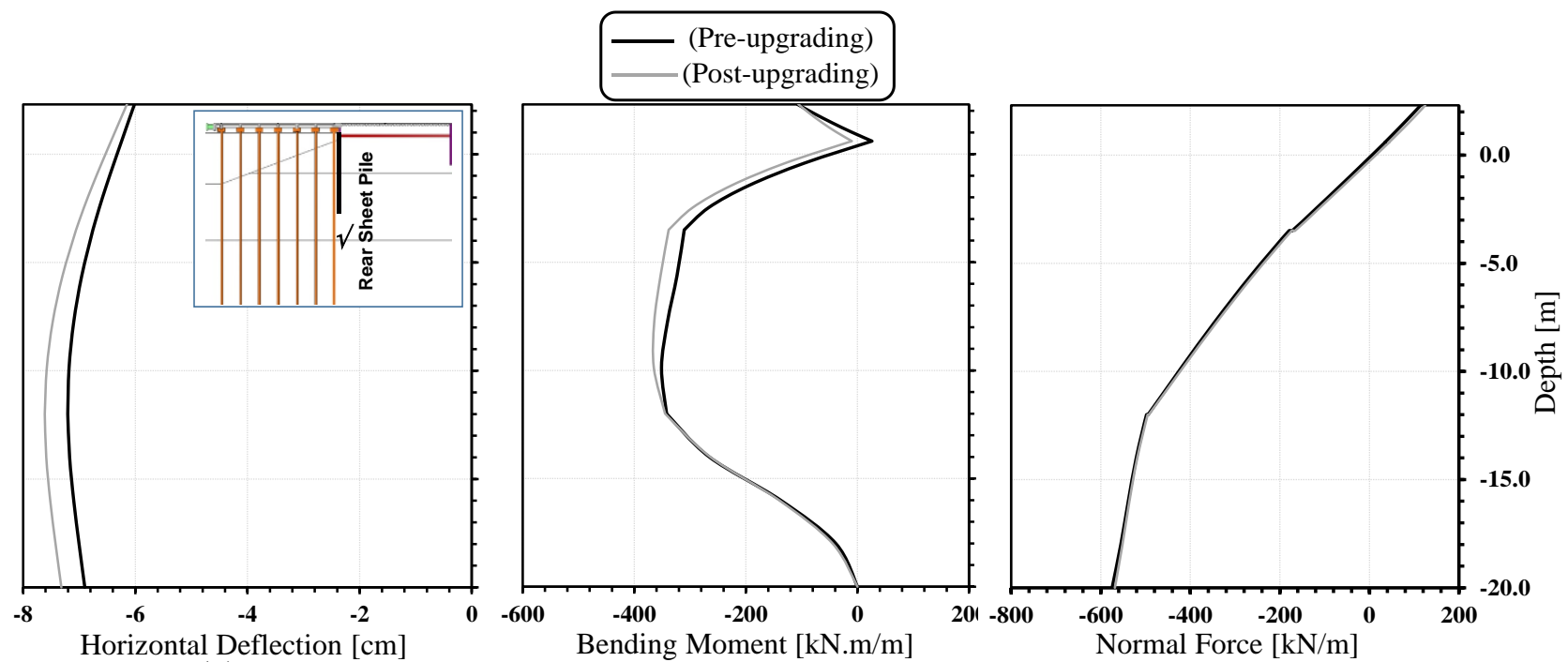

Figure 19): Comparison between pre- and post-upgrading cases for Rear sheet pilếfor: (a) Horizontal displacement, (b) Bending moment, and (c) Normal force. 


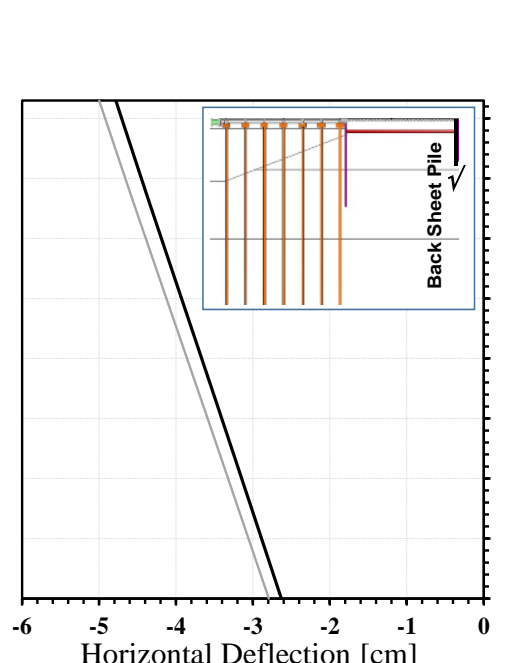

(a)

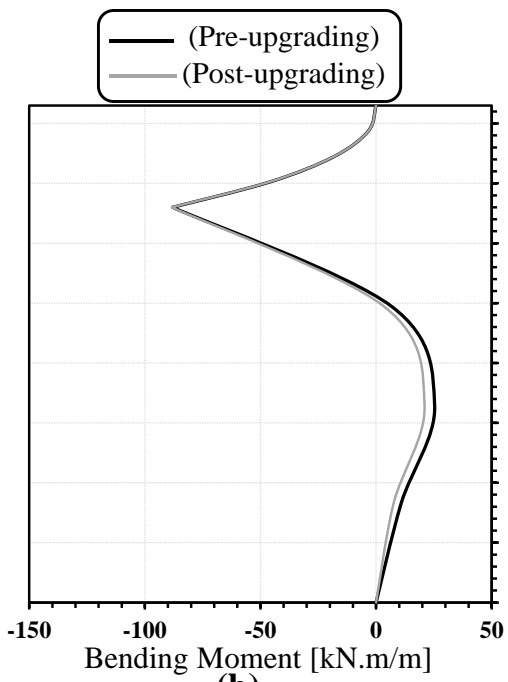

(b)

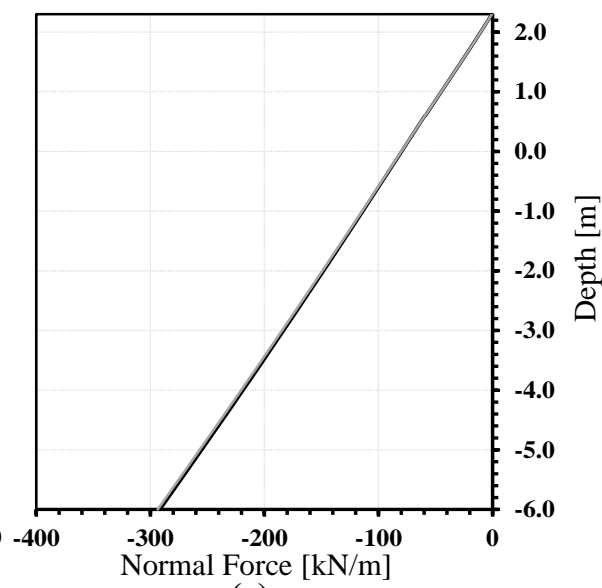

(c)

Figure 12: Comparison between pre- and post-upgrading cases for Back sheet pile for: (a) Horizontal displacement, (b) Bending moment, and (c) Normal force

\section{CONCLUSIONS}

The present study was carried out to evaluate numerically, using the numerical model PLAXIS 2D, the possibility to upgrade the existing open-piled quay wall structure of the container terminal of Port Said West port. The upgrading made to accommodate the berth deepening and the heavier new container crane loads. The selected rehabilitation technique consisting of new fender piles and new box sheet pile panels to resist deepening to the level $-16.0 \mathrm{~m}$ plus the increase of the crane loads from $250 \mathrm{KN} / \mathrm{m}^{\prime}$ to $300 \mathrm{KN} / \mathrm{m}^{\prime}$. The evaluation had been carried out through the review of the original design and subsequent improvement analyses under the development two cases defined as Pre- and Post-upgrading cases. The computation had been carried out with respect to the behavior of each model for the soil and the structure domains. The analyzed results of the study including deformations, capacities of structural elements, settlements, soil stresses values and overall stability limitations obtained for both cases had been presented. It could be concluded that the structure after upgrading was able to keep the stability of the soil to its previous levels before upgrading. Furthermore, the selected rehabilitation technique could help the existing quay wall structure elements to resist the additional straining actions resulted from the deepening effect plus the increase in crane loads.

At the end, the author recommended to extend this research study with 3D numerical computation including the effect of dynamic loads.

\section{REFRENCES}

[1] ACI 318-95 (1995), "American Building code requirements for structural concrete", American concrete institute, USA.
[2] Brinkqreve, R.B.J, Broere, W., and Watherman, D., (2004), "PLAXIS - 2D Version 8 Manual", Plaxis BV, Delft, the Netherlands.

[3] Cornell, C., Bohlen, W., Kumar, V., and Reyes, A., (2007), "Upgrade of berth 15 for gantry cranes Panama Ports Company, Balboa, Republic of Panama", 11 th International Conference on Ports, San Diego, California, USA.

[4] De Gijt, J.G., and Broeken, M.L., (2013), "Quay Walls, Second Edition", CRC Press, 2013 ISBN: 978-1-315-77831-0.

[5] Deblauwe, B., Sanders, F., De Clerck, D., and Van Parys, D., (2013), "Port of Zeebrugge - deepening of container handling Zeebrugge quay wall", IABSE Symposium Report", Vol. 99(1), pp. 20292036.

[6] Douairi M., (2013), "Research into deepening options for quay walls", MSc. Thesis, Delft University of Technology.

[7] El-Naggar, M., (2010), "Enhancement of steel sheet-piling quay walls using grouted anchors", Journal of Soil Science and Environmental Management, Vol. 1(4), pp. 69-76.

[8] Elskensl, F., and Bols, L., (1998), "Innovative techniques for quay wall renovation and stabilization" Transactions on the Built Environment, Maritime Engineering and Ports, Vol 36, pp. 127132.

[9] Farshidfar, N., Nayeri, A., (2015), "Slope Stability Analysis by Shear Strength 
Reduction Method", Civil Engineering and Urbanism Journal, Vol.5, pp. 35-37.

[10] Galal, E.M., Mourad, M.H., and Tolba, E.R., (2016), "Comparison between 2D and 3D Analysis of Open-piled Quay Walls", Ninth International Conference on Coastal and Port Engineering in Developing Countries - IX PIANC-COPEDEC, Rio de Janeiro, Brasil, October 2016.

[11] Habets, C.J.W., Peters, D.J., De Gijt, J.G., Metrikine, A.V., and Jonkman, S.N., (2016), "Model solutions for performance-based seismic analysis of an anchored sheet pile quay wall", International Journal of Civil, Environmental, Structural, Construction and Architectural Engineering, Vol. 10(3), pp. 278- 290.

[12] Mollahasani, A., (2014), “Application of submerged grouted anchors in sheet pile quay walls", Ph.D. thesis, Civil and Environmental Engineering Dept., University of Bologna, Italy.

[13] Muthukkumaran, K., and Sundaravadivelu, $R$., (2007), "Numerical modeling of dredging effect on berthing structure", Acta Geotechnica International Journal of Geoengineering, Vol. 2, pp.249-259.

[14] Oung, O., and Brassinga, H., (2015), "Uncertainties in redesigning an existing quay wall”, Geotechnical Safety and Risk V, DOI: 10.3233/978-1-61499-580-7-407.

[15] Paparis, B., Quadagno, M., Buzzoni, G., McQueen, J., and Lizzo, J., (2004), "Modernizing a three decade old wharf structure for the next generation of container ships", In Proceeding of Ports Conference, American Society of Civil Engineers Journal, Houston, Texas, USA, DOI: $10.1061 / 9780784407271$.

[16] PIANC MarCom (2001), "Seismic Design Guidelines for Port Structures". Working Group no. 34 of the Maritime Navigation Commission, International Navigation Association.

[17] PIANC MarCom (2015), "Upgrade of Port Terminals by increasing dredged depth", Working Group no. 164 of the Maritime Navigation Commission, International Navigation Association.

[18] Premalatha, P.V., Muthukkumaran. K., and Jayabalan, P., (2011), "Effect of dredging and tie-rod anchor on the behavior of berthing structure". International Journal of Engineering Science and Technology (IJEST), Vol. 3(6), pp. 5099- 5115

[19] Randolph, M.F., (1981), "Pilot study of lateral loading of piles due to movement caused by embankment loading", Report for the UK Department of Transport (HECB), Cambridge University.

[20] Subha, I.P., (2012), "Behavior of an Open Type Berthing Structure under Earthquake Condition-A Numerical Approach", International Journal of Engineering Research and Applications (IJERA), Vol. 2(1), pp. 36-40.

[21] Tolba, R.E., Galal, E.M., and Mourad, M.H., (2017), "Effect of the frontal deepening of quay wall for the East Port of Port Said', Malaysian Journal of Civil Engineering, Vol 29 (2), (In Print).

[22] Varatharaj, R.S., Pratheepan, P.K., Arulmoli, A.K., Schulze, C., and Chan, D., (2016), "Seismic improvements and upgrade of a wharf using an innovative ground improvement scheme", 14th International Conference, New Orleans, LA, USA. 